УДК 343.1

DOI https://doi.org/10.51989/NUL.2021.6.34

\title{
ОРГАНІЗАЦІЙНО-ТАКТИЧНІ ОСОБЛИВОСТІ ПРОВЕДЕННЯ СЛІДЧИХ (РОЗШУКОВИХ) ДІЙ ПІД ЧАС РОЗСЛІДУВАННЯ КОРИСЛИВО-НАСИЛЬНИЦЬКИХ ЗЛОЧИНІВ, ВЧИНЕНИХ ЩОДО ІНОЗЕМЦІВ
}

\author{
Фаєр Iгор Васильович, \\ здобувач наукового ступеня доктора філософії \\ кафедри криміналістики та судової медицини \\ Національної академії внутрішніх справ
}

Під час розслідування корисливо-насильницьких злочинів, учинених щодо іноземців, слідчий проводить слідчі (розшукові) дії як головний засіб збирання доказів у кримінальному провадженні відповідно до вимог кримінального процесуального законодавства та згідно з розробленими криміналістичними рекомендаціями. Однак за такої слідчої ситуації варто враховувати і низку організаційно-тактичних особливостей. На їх висвітлення і спрямована наукова публікація.

По-перше, під час проведення слідчих (розшукових) дій щодо іноземців треба брати до уваги їхній правовий статус і зумовлені цією обставиною особливі вимоги до проведення слідчих (розшукових) дій.

По-друге, під час підготовки до проведення слідчих (розшукових) дій слідчому необхідно виконати такі організаційні завдання: забезпечити реалізацію права потерпілого іноземця на представника, перекладача та захисника; забезпечити можливість застосування технічних засобів тощо. Також слідчий повинен застосувати організаційні заходи для забезпечення участі спеціаліста, понятих, законного представника тощо. Запорукою успішного проведення слідчої (розшукової) дії є ретельне вивчення особи іноземця.

По-четверте, необхідно застосувати комплекс організаційних заходів для виконання тактичного завдання - установлення психологічного контакту. Велике значення за даних умов мають низка чинників: комфортне приміщення для проведення слідчих (розшукових) дій, доброзичливе ставлення слідчого, інших учасників кримінального провадження. Зазвичай іноземець, який став жертвою злочину, перебуває у стані тривоги, роздратування, недовіри. Нерідко особі важко зрозуміти особливості вітчизняного кримінального провадження, що може спричинити негативне ставлення до правоохоронців. Слідчий повинен проявити тактичну майстерність за такої слідчої ситуації, застосувати тактичні прийоми роз'яснення, переконання. Слідчий може скористатися допомогою спеціаліста - знавця певного народу, етносу, нації. Він допоможе роз'яснити культурні та релігійні особливості, зважання на які може стати запорукою встановлення психологічного контакту.

Ключові слова: слідчі (розшукові) дії, іноземець, корисливо-насильницький злочин, тактика, огляд, допит.

Faier Ihor. Organizational and tactical features of investigative (search) actions during the investigation of mercenary and violent crimes committed against foreigners

During the investigation of mercenary and violent crimes committed against foreigners, the investigator conducts investigative (search) actions as the main means of gathering evidence in criminal proceedings in strict accordance with the requirements of criminal procedure legislation and in accordance with the developed forensic recommendations. However, in such an investigative situation, a number of organizational and tactical features should be taken into account. This scientific publication is aimed at their coverage.

First, when conducting investigative (search) actions against foreigners, one should take into account their legal status and the special requirements for conducting investigative (search) actions due to this circumstance.

Secondly, during the preparation for the investigative (search) actions, the investigator should solve the following organizational tasks: to ensure the realization of the right of the injured 
foreigner to a representative, translator and defense counsel; to provide an opportunity of application of technical means, etc. The investigator must also take organizational measures to ensure the participation of specialists, witnesses, legal representatives, etc. The key to successful investigative (search) action is a thorough study of the identity of a foreigner.

Fourth, it is necessary to apply a set of organizational measures to perform a tactical task to establish psychological contact. Under these conditions, a number of factors are important: a comfortable room for investigative (search) actions, a friendly attitude of the investigator, other participants in criminal proceedings. Usually a foreigner who has become a victim of a crime feels a state of anxiety, irritation, distrust. It is often difficult for a person to understand the peculiarities of domestic criminal proceedings, which can cause a negative attitude towards law enforcement officers. The investigator must show tactical skill in such an investigative situation, apply tactical methods of explanation, persuasion. The investigator can use the help of a specialist - an expert on a particular people, ethnic group, nation. It will help to explain the cultural and religious peculiarities, the observance of which can be the key to establishing psychological contact.

Key words: investigative (search) actions, foreigner, mercenary-violent crime, tactics, review, interrogation.

Постановка проблеми. Учинення корисливо-насильницьких злочинів стосовно іноземців має особливий суспільний резонанс, оскільки, окрім завдання шкоди людині - потерпілому від злочину, завдається шкода іміджу України як цивілізованої європейської держави. Важливою $€$ та обставина, що для досягнення завдань кримінального провадження, розслідування корисливо-насильницького злочину, скоєного щодо іноземця, слідчий повинен провести слідчі (розшукові) дії як головний засіб збирання доказів у кримінальному провадженні відповідно до вимог кримінального процесуального законодавства та згідно з розробленими криміналістичними рекомендаціями. Вказана проблематика не досить висвітлена в науковій літературі, дана обставина зумовила тему наукової публікації.

Аналіз останніх досліджень і публікацій. Проблеми проведення слідчих (розшукових) дій з іноземцями розкривалися у працях П.Г. Назаренка [1] та Ю.М. Чорноус [2]. Однак у наукових працях не висвітлено проблеми проведення слідчих (розшукових) дій за умов розслідування корисливо-насильницьких злочинів, учинених щодо іноземців. У розслідуванні вказаних кримінальних правопорушень $\epsilon$ організаційно-тактичні особливості, які мають враховуватися слідчим і $\epsilon$ безпосереднім предметом наукового дослідження.

Виклад основного матеріалу дослідження. Як свідчать статистичні дані Офісу Генерального прокурора, кількість учинених кримінальних правопорушень $\epsilon$ загрозливою. Так, протягом 2019 р. потерпілими від кримінальних правопорушень стали 1924 іноземці, протягом 2020 р. - 980 іноземців, а за 10 місяців 2021 р. статусу потерпілого у кримінальних провадженнях набули 919 іноземців [3]. Однак і дані цифри не відображають реального стану справ, $\epsilon$ заниженими внаслідок латентності кримінальних правопорушень. Окрім того, зниження кількості вчинених щодо іноземців кримінальних правопорушень у 2020 та 2021 рр. пов'язано з негативними наслідками пандемії, запровадженням карантинних заходів в Україні згідно з постановою Кабінету Міністрів України від 11 березня 2020 р. № 211 «Про запобігання поширенню на території України гострої респіраторної хвороби, спричиненої коронавірусом SARS-CoV-2" [4] та системи карантинних обмежень у всьому світі. Вказана обставина румовила суттєве зниження активності міжнародних контактів у суспільному житті, на фінансових ринках і в туристичній галузі.

Водночас у нашій країні тривожними $\epsilon$ показники щодо вчинених корисливонасильницьких злочинів. Така тенденція спостерігається щодо трьох основних груп корисливо-насильницьких злочинів за спрямованістю посягань:

1) проти життя та здоров'я особи: убивства з корисливих мотивів, убивства, учинені на замовлення;

2) проти власності: грабежі, розбої, вимагання;

3) проти громадської безпеки: бандитизм. 
Так, за статистичними даними Офісу Генерального прокурора, у 2019/2020 рр. та за 10 місяців 2021 р. було вчинено 90 / 59 / 44 вбивства з корисливих мотивів (п. 6 ч. 2 ст. 115 Кримінального кодексу (далі - КК) України), 14 / 18 / 6 убивств на замовлення (п. 11 ч. 2 ст. 115 КК України), 11129 / 7464 / 4226 грабежів (ст. 186 КК України), 1869 / 1343 / 800 розбоїв (ст. 187 КК України), 672 / 649 / 540 вимагань (ст. 189 КК України), 15 / 20 / 9 бандитських нападів (ст. 257 КК України) [3]. Загалом спостерігається позитивна тенденція, пов'язана зі зниженням рівня корисливо-насильницької злочинності, однак статистичні дані все ще залишаються тривожними і вимагають ефективних заходів реагування.

Причинами вчинення корисливонасильницьких злочинів щодо іноземців $\epsilon$ економічна криза, зубожіння населення, моральна деградація частини суспільства, бажання збагатитися будь-яким шляхом. За таких умов іноземці, які характеризуються ознаками віктимності, привертають увагу осіб зі злочинним досвідом, які бажають легкої наживи й готові досягти своїх цілей, ігноруючи принцип верховенства права, застосовують незаконні й аморальні засоби, методи і прийоми діяльності. Окреслена ситуація вимагає від правоохоронних органів застосування комплексу заходів для гарантування безпеки, прав і свобод іноземців, а також реалізації запобіжної і правозахисної функцій.

Як уже було зазначено, під час розслідування корисливо-насильницьких злочинів, учинених щодо іноземців, необхідне організаційно врегульоване й тактично правильне проведення слідчих (розшукових) дій. Структура слідчої (розшукової) дії $\epsilon$ типовою і містить такі елементи, як: 1) підготовка; 2) безпосереднє проведення (робочий етап); 3) фіксація. Залежно від слідчої ситуації кожна слідча (розшукова) дія має індивідуальний організаційно-тактичний зміст.

Згідно з даними слідчої практики, під час розслідування корисливо-насильницьких злочинів, скоєних щодо іноземців, проводяться такі слідчі (розшукові) дії: огляд, зокрема й такий його різновид, як огляд місця події; допит, а також такий його різновид, як одночасний допит двох чи більше вже допитаних осіб; обшук; судові експертизи. Перелічені слідчі (розшукові) дії проводилися в усіх вивчених нами кримінальних провадженнях. Також здебільшого проводилися такі слідчі (розшукові) дії, як пред'явлення для впізнання, слідчий експеримент, освідування особи, отримання зразків для експертизи.

Важливо, що під час проведення слідчих (розшукових) дій щодо іноземців треба враховувати їхній правовий статус і зумовлені цією обставиною особливі процесуальні засади проведення слідчих (розшукових) дій.

Так, кримінальне провадження щодо іноземних громадян здійснюється відповідно до норм Кримінального процесуального кодексу (далі - КПК) України, за винятком осіб, які користуються дипломатичним імунітетом. Слідчі (розшукові) дії з іноземцями проводяться відповідно з їхнім правовим статусом, визначеним законодавством України.

У процесі підготовки до проведення слідчих (розшукових) дій із потерпілими іноземцями слідчому треба вирішити такі організаційні завдання:

- забезпечити реалізацію права потерпілого іноземця на представника (п. 8 ч. 1 ст. 56 КПК України);

- забезпечити реалізацію права потерпілого іноземця на перекладача (п. 9 ч. 1 ст. 56 КПК України);

- за умови встановлення, що особи не володіють мовою, якою ведеться кримінальне провадження, - забезпечити обов'язкову участь захисника (ст. 52 КПК України);

- забезпечити реалізацію права потерпілого іноземця на застосування технічних засобів під час проведення процесуальних дій за його участю (п. 12 ч. 1 ст. 56 КПК України).

Також слідчий повинен застосувати організаційні заходи для забезпечення участі спеціаліста (ст. 71 КПК України), понятих (ч. 7 ст. 223 КПК України), законного представника (ст. ст. 44, 59, 226 КПК України) та інших.

Перед початком слідчої (розшукової) дії необхідно сформувати характеристику особи іноземця. Треба з'ясувати дані про державу громадянства іноземця, підстави і тривалість перебування на території 
України, уточнити наявність необхідних документів. Окрім того, важливо якомога детальніше дізнатися соціально-біографічні дані. Варто подбати, щоб документи, які будуть надаватися іноземцю (перелік його прав і обов'язків, відомості довідкового характеру, окремі фрагменти з матеріалів кримінального провадження, довідки за результатами перевірки за базами даних), були завчасно перекладені мовою, якою бажає спілкуватися іноземець. Адже згідно із ч. 3 ст. 29 КПК України слідчий суддя, суд, прокурор, слідчий забезпечують учасникам кримінального провадження, які не володіють чи не досить володіють державною мовою, право давати показання, заявляти клопотання і подавати скарги, виступати в суді рідною або іншою мовою, якою вони володіють, користуватися, у разі необхідності, послугами перекладача в порядку, передбаченому КПК України [5].

Необхідно застосувати комплекс організаційних заходів для наступного виконання тактичного завдання - встановлення психологічного контакту. Велике значення за даних умов має власне комфортне приміщення для проведення слідчих (розшукових) дій, доброзичливе ставлення слідчого, інших учасників кримінального провадження. Зазвичай іноземець, який став потерпілим від злочину, може перебувати у стані тривоги, роздратування, недовіри. Нерідко іноземцю важко зрозуміти особливості вітчизняного кримінального провадження, що може спричинити негативне ставлення до правоохоронців. Слідчий повинен проявити тактичну майстерність за такої слідчої ситуації. Можуть залучатися для надання допомоги фахівці - знавці певного народу, етносу, нації. Вони допоможуть роз'яснити культурні та релігійні особливості, дотримання яких може стати запорукою встановлення психологічного контакту.

Під час безпосереднього проведення робочої стадії слідчої (розшукової) дії слідчому треба застосовувати низку організаційно-тактичних заходів із метою контрою слідчої (розшукової) дії. Варто робити паузи під час спілкування з іноземцем, щоб перекладач зміг надати інформацію зрозумілою потерпілому мовою і перекласти слова власне іноземця.
На організацію й тактику проведення слідчих (розшукових) дій впливає і термін перебування іноземця в Україні, особливо коли він $\epsilon$ потерпілим або свідком у кримінальному провадженні. у таких умовах дії повинні бути проведені оперативно і настільки якісно, щоб потім не було потреби в їх повторному проведенні [6, с. 935]. Несвоєчасне і неякісне проведення слідчих (розшукових) дій може спричинити ситуацію, за якої повторне чи додаткове проведення слідчої (розшукової) дії буде неможливим чи неефективним.

Наступним організаційно-тактичним завданням $\epsilon$ забезпечення ефективної фіксації слідчої (розшукової) дії. Протокол та додатки до нього оформлюються з дотриманням вимог КПК України та криміналістичних рекомендацій. Окрім того, слідчому треба враховувати, що вказані вище документи мають бути перекладені мовою, яку розуміє іноземець.

Як зазначає П.Г. Назаренко, слідчі (розшукові) дії за участю іноземців доцільно фіксувати за допомогою технічних засобів (фотографування, відеозапис). Відеозапис дозволяє максимально зафіксувати обстановку слідчої (розшукової) дії, живу мову іноземного учасника слідчої (розшукової) дії. Відеозапис має велике значення і тому, що перебування іноземця на території України часто обмежено часом, отже, чим більше інформації вдасться отримати, тим успішніше буде подальше розслідування. Використання відеозапису може навіть сприяти виявленню фактів завідомо неправдивого перекладу, уточненню перекладачем пояснень іноземця стосовно окремих обставин кримінального правопорушення [1, с. 88$]$.

Особливістю організаційно-тактичних засад проведення огляду під час розслідування корисливо-насильницьких злочинів, учинених щодо іноземців, $\epsilon$ необхідність дослідження досить інформативної слідової картини, яка утворюється внаслідок застосування фізичного насилля шляхом нанесення ударів, побиття, застосування вогнепальної та холодної зброї.

Важливі положення Інструкції про порядок залучення працівників органів досудового розслідування поліції й Експертної служби Міністерства внутрішніх 
справ (далі - МBC) України як спеціалістів для участі у проведенні огляду місця події, що затверджена наказом МВС України від 3 листопада 2015 р. №1339 [7]. Нормативно-правовий акт передбачає, що в разі вчинення низки злочинів корисливо насильницької спрямованості, а саме: вбивства або умисного тяжкого тілесного ушкодження, що спричинило смерть потерпілого, із застосуванням вогнепальної зброї; розбійного нападу із застосуванням вогнепальної зброї з постраждалими особами тощо, необхідно залучати до огляду місця події спеціалізовану пересувну криміналістичну лабораторію Експертної служби МВС.

У результаті проведеного аналізу емпіричних даних варто акцентувати увагу на специфічних об'єктах огляду - документах, що посвідчують особу іноземця. Це документи, що засвідчують особу іноземця, надають право на перебування в Україні, підтверджують факт прибуття або час виїзду іноземців з території України. Метою таких оглядів може бути встановлення особи іноземця; особливостей правового статусу іноземців в Україні, термінів перебування іноземців в Україні, місця перебування іноземців у конкретний проміжок часу, фактів перебування іноземців на території інших іноземних держав, часу і місця перетину іноземцем державного кордону України, порушення іноземцем міграційного законодавства України, отримання установчих відомостей щодо особи іноземця тощо [8, с. 17].

Особливу увагу необхідно приділяти складанню процесуальних документів, зокрема протоколів огляду місця події, оскільки копії цих документів необхідно перекласти мовою, яку розуміє іноземець.

Треба звертати увагу й на допит іноземця. потерпілого від корисливо-насильницького злочину. Необхідно подбати про залучення перекладача й інших учасників слідчої (розшукової) дії. За такої слідчої ситуації повинні застосовуватися особливі тактичні прийоми, з урахуванням психологічного механізму їх реалізації, що передбачає: безпосередню чи опосередковану взаємодію між особою, яка здійснює кримінальне провадження, та ії респондентами; його психологічну спрямованість, пов'язану з відтворенням події, що трапи- лася, актуалізацією забутого, викриттям неправди, пошуком прихованого; психологічний ефект від використання тактичного прийому (пов'язаний із необхідністю отримання правдивих показань, виявленням слідів кримінального правопорушення) [9].

Треба планувати тактичні прийоми, а також зміст питань, форму їх виразу. Питання під час допиту повинні бути логічно правильно побудовані, зрозумілі, етичні. Варто пам'ятати про національні, релігійні, культурні особливості, традиції, ставитися до них із повагою.

3 огляду на криміналістичну характеристику корисливо-насильницьких злочинів, потерпіла особа зазнає фізичного та психологічного насилля, перебуває у стані стресу, тому для надання допомоги потерпілому та з метою отримання повних і достовірних показань до проведення такої слідчої (розшукової) дії може залучатися психолог. Бажано, щоб психолог володів мовою, якою спілкується іноземець, хоча й допомога перекладача не виключається. Під час вибору перекладача та психолога слідчому доцільно використовувати можливості МВС України, Департаменту міжнародного поліцейського співробітництва Національної поліції України.

Для розслідування корисливо-насильницьких злочинів, учинених щодо іноземців, необхідне використання спеціальних знань. Під час розслідування кримінальних правопорушень спеціалісти залучаються до участі у слідчих (розшукових) діях у разі: а) відсутності у слідчого спеціальних знань і навичок, необхідних для кваліфікованої підготовки та проведення слідчої (розшукової) дії; б) неналежного володіння слідчим прийомами та засобами швидкого і якісного виконання певної роботи, що потребує спеціальних знань і навичок; в) необхідності з етичних чи тактичних міркувань доручити виконання певних дій спеціалістові; г) одночасного застосування кількох засобів криміналістичної техніки; ґ) необхідності виконати значний обсяг роботи, яка потребує спеціальних знань та навичок [10, с. 524].

Висновки. У розслідуванні корисливонасильницьких злочинів, скоєних щодо іноземців, необхідно брати до уваги низку організаційно-тактичних особливостей. 
До однієї з них належить використання спеціальних знань, що реалізується у формах: залучення спеціалістів для участі у проведенні слідчих (розшукових) дій; проведення судових експертиз; одержання консультацій в усній та письмовій формах.

Поширеною формою використання спеціальних знань у розслідуванні корисливонасильницьких злочинів, учинених щодо іноземців, $€$ консультативна допомога спеціалістів. Така допомога надається в усній або письмовій формі. Письмова консуль- тація може надаватися як фізичними, так і юридичними особами (судово-експертні установи, заклади вищої освіти).

Що стосується застосування спеціальних знань під час проведення слідчих (розшукових) дій за участю іноземців, то вважаємо доцільним додати таку підставу, як надання допомоги у вивченні особи іноземця. Реалізація вказаної пропозиції дозволить слідчому ефективно підготуватися до проведення слідчих (розшукових) дій, провести їх максимально ефективно.

\section{ЛITEPATУPA:}

1. Назаренко П.Г. Особливості провадження досудового слідства у кримінальних справах за участю іноземців : дис. ... канд. юрид. наук : 12.00.09. Харків, 2006. 196 с.

2. Чорноус Ю.М. Особливості тактики слідчих (розшукових) дій за участю іноземців. Криміналістичний вісник : науково-практичний збірник. 2015. № 2 (24). С. 62-70. 3.

3. Єдиний звіт про кримінальні правопорушення по державі (за 2019, 2020, 2021 рр.). Офіс Генерального прокурора. URL: https://www.gp.gov.ua/ua/stat_n_st?dir_ id $=114140 \&$ libid $=100820 \& \mathrm{c}=$ edit\&_c=fo.

4. Про запобігання поширенню на території України гострої респіраторної хвороби , спричиненої коронавірусом SARS-CoV-2 : постанова Кабінету Міністрів України від 11 березня 2020 р. № 211. Верховна Рада України. URL: https://zakon.rada.gov.ua/laws/show/211-2020$\%$ D0\%BF\#Text.

5. Кримінальний процесуальний кодекс України : Закон України від 13 квітня 2012 р. № 4651-VI. Верховна Рада України : вебсайт. URL: http://zakon.rada.gov.ua/laws/ show/4651-17.

6. Криминалистика : учебник для высших учебных заведений / Т.В. Аверьянова и др. ; под ред. Р.С. Белкина. Москва : Норма - Инфра-М, 1999. 974 с.

7. Про затвердження Інструкції про порядок залучення працівників органів досудового розслідування поліції та Експертної служби Міністерства внутрішніх справ України як спеціалістів для участі у проведенні огляду місця події, затв. наказом Міністерства внутрішніх справ України від 3 листопада 2015 р. № 1339. Верховна Рада України : вебсайт. URL: https://zakon.rada.gov.ua/laws/show/z1392-15\#Text.

8. Процесуальні та тактичні особливості провадження окремих процесуальних дій з участю іноземців : методичні рекомендації. Луганськ : Головне слідче управління МВС України ; Луганський державний університет внутрішніх справ імені Е.О. Дідоренка, 2012. 47 с.

9. Чорноус Ю.М. Психологічні основи реалізації тактичних прийомів. Юридична психологія : науковий журнал. Київ : Нац. акад. внутр. справ, 2020. № 1 (26). С. 13-22. DOI: $10.33270 / 03202601.13$.

10. Криміналістика : підручник / В.В. Пясковський та ін. Київ, 2015. 544 с. 